
в современных медиатекстах (на материале татарского языка)

Гиниятуллина Л. М., Шакурова М. М.

Аннотация. Цель исследования - доказать грамматическую и семантическую целостность компонентов сложных синтаксических целых в современных медиатекстах. На материале текстов сообщений газеты «Ватаным Татарстан» («Моя родина Татарстан») и информационного агентства «Татаринформ» рассматриваются смысловые отношения между предложениями сложных синтаксических целых. Научная новизна исследования заключается в разработке нового подхода к анализу сложных синтаксических целых, вычлененных из современных медиатекстов на татарском языке, учитывающих взаимообусловленность структурных и семантических особенностей. В результате анализа выявляется функционально-прагматическая сущность сложных синтаксических целых с разными видами синтаксических отношений.

\title{
EN Structural and Semantic Types of Complex Syntactic Unities in Modern Media Texts (by the Material of the Tatar Language)
}

\author{
Giniyatullina L. M., Shakurova M. M.
}

\begin{abstract}
The study aims to prove grammatical and semantic integrity of the components of complex syntactic unities in modern media texts. Using texts of the reports from the newspaper "Vatanym Tatarstan" ("My Homeland Tatarstan") and the media outlet "Tatar-Inform", the researchers consider the semantic relations between sentences of complex syntactic unities. Scientific novelty of the study lies in developing a new approach to analysing complex syntactic unities identified in modern media texts in the Tatar language, taking into account the interdependence of their structural and semantic features. As a result of the analysis, the functional-pragmatic essence of complex syntactic unities with different types of syntactic relations has been determined.
\end{abstract}

\section{Введение}

Текст для исследователя является реальным заменителем связной речи. Для того чтобы изучить текст в целом, следует проанализировать элементы, отдельные стороны данного целого.

Сложное синтаксическое целое (далее - ССЦ) является одним из элементов текста. По словам Н. С. Поспелова (1948), ССЦ - это «группа предложений, синтаксически объединенных различными средствами и способами» (с. 41).

В научной литературе не так много работ, посвященных комплексному исследованию сложных синтаксических целых в аспекте единства содержания и структурного выражения. Актуальность настоящей статьи обусловлена потребностью более полного научного исследования структурных особенностей сложного синтаксического целого в современных медиатекстах. Выявление структурно-семантических особенностей сложных синтаксических целых в современных медиатекстах может послужить основой для дальнейшего исследования ССЦ как особой синтаксико-стилистической единицы в системе других синтаксических единиц с целью определения места ССЦ в этой системе.

Для достижения цели исследования необходимо решить следующие задачи: во-первых, выявить виды синтаксических отношений между компонентами сложных синтаксических целых в современных медиатекстах; во-вторых, описать структурно-семантические типы сложных синтаксических целых в вычлененных из медиатекстов ССЦ и, наконец, исследовать компоненты сложных синтаксических целых на основе их структуры и семантики.

Решение поставленных задач стало возможно благодаря теоретической базе, представленной трудами М. З. Закиева (Зәкиев, 1974; Закиев, 1995; Зәкиев, 2017), С. М. Ибрагимова (Ибраһимов, 2008), Ф. С. Сафиуллиной (1993), И. М. Низамова (2012), В. З. Гарифуллина (1997; 2010). 
В работе использовались различные взаимодополняющие методы исследования: описательно-аналитический, метод комплексного анализа; метод лингвистического наблюдения и описания конкретных языковых фактов с целью получения обобщенных данных.

Практическая значимость работы обусловлена тем, что ее результаты могут быть использованы в построении учебных курсов «Современный татарский язык», «Стилистика», «Лингвистический анализ текста». В частности, материалы работы могут стать частью содержания спецкурсов и спецсеминаров по проблемам текста.

Сложное синтаксическое целое в русской лингвистике изучено такими учеными, как А.А. Потебня, А. М. Пешковский, В. В. Виноградов, Н. С. Поспелов, Н. Ф. Яковлев, Г. О. Винокур, И. А. Фигуровский, И. Р. Гальперин, Л. М. Лосева, Г. Я. Солганик, И. С. Папуша, Т. Ф. Глебская и др. Определению ССЦ в языкознании уделено большое внимание и применяется несколько терминов для его обозначения: сложное синтаксическое целое, микротекст, сверхфразовое единство, микрофразовое единство, суперфраза, прозаическая строфа, абзац, цепь предложений, дискурс и др. Наиболее часто встречается термин «сложное синтаксическое целое».

В татарском языкознании изучению текста уделили внимание А.Н. Максуди, Г. Г. Ибрагимов, Г. Х. Алпаров, Д. Д. Валиди, Х. Г. Бадиги, Х. Р. Курбатов, В. Х. Хаков, Ш. С. Ханбикова, М. З. Закиев, С. М. Ибрагимов, Ф. С. Сафиуллина, И. М. Низамов, И. Б. Баширова, В. З. Гарифуллин, М. М. Шакурова и другие. В татарской лингвистике также наблюдается наличие нескольких терминов для обозначения элемента текста: микротекст, синтаксическое целое (синтаксик бөтен), абзац, цепь предложений, период (тезем). Часто термины «синтаксическое целое» и «микротекст» рассматриваются как идентичные понятия.

\section{Основная часть}

В лингвистике ССЦ рассматривается как сочетание предложений, связанных между собой семантическими, структурными и грамматическими средствами связи.

В ходе исследования был отобран фактический материал из общественно-политической газеты на татарском языке, издающейся в Татарстане «Ватаным Татарстан» («Моя родина Татарстан») (номера за 2013-2021 годы) и тексты сообщений информационного агентства «Татар-информ». В результате их анализа были выявлены ССЦ с нижеследующими смысловыми отношениями частей:

- ССЦ с сочинительными отношениями;

- ССЦ с противительными отношениями между компонентами;

- ССЦ с сопоставительными отношениями между предложениями;

- ССЦ с причинными отношениями между предложениями;

- ССЦ со следственными отношениями между компонентами;

- ССЦ с условными отношениями между предложениями;

- ССЦ с присоединительными отношениями частей.

Проведенное нами исследование показало, что для современных медиатекстов наиболее характерными являются ССЦ с сочинительными отношениями, где компоненты равноправны.

Например: Татарстан Президенты аппараты житәкчесе Әсгать Сәфәров республиканың субъектлардагы вәкилләре белән 2021 елгы жанисәпкә багышланган онлайн-киңәшмә уздырды, дип хәбәр итә Татарстан Республикасының Россиядаге Тулы вәкаләтле вәкиллегенең матбугат хезмәте.

Киңәшмддә Татарстан Премьер-министры урынбасары, Бөтендөнья татар конгрессының Милли шура рәисе Васил Шәйхразиев, Татарстанның Башкортстандагы, Санкт-Петербургтагы һәм Ленинград өлкәсендәге, Свердловск өлкасендәге даими вәкилләре дә катнашты.

Алар күпмилләтле Россия өчен жанисәпнең мөһимлеген искәртте (Татар-информ, 30.10.2021). / Как сообщает пресс-служба Полномочного представительства Республики Татарстан в Российской Федерации, руководитель Аппарата Президента РТ Асгат Сафаров провел онлайн-совещание, посвященное вопросам переписи населения 2021 года, где приняли участие представители республики в субъектах.

В совещании приняли участие заместитель премьер-министра РТ, председатель нацсовета «Милли Шура» Всемирного конгресса татар Васил Шайхразиев, постоянные представители Татарстана в Башкортостане, Санкт-Петербурге и Ленинградской области, Свердловской области.

Они подчеркнули важность переписи населения для многонациональной России (здесь и далее перевод авторов статьи. - Л. Г., М. Ш.).

В таких ССЦ наблюдается тесная смысловая связь частей. В них последовательно раскрывается основная тема ССЦ. Целостность компонентов ССЦ обусловлена тесной внутренней связью, направленностью на выражение единого глубинного смысла. Сочинительная связь частей ССЦ представляется разными видами.

В нашем примере видно, что основная тема (жанисәпкә багышланган онлайн-киңдшмә - онлайн-совещание, посвященное переписи населения) раскрывается в последующих двух предложениях, которые в свою очередь дополняют друг друга. Но содержание двух последних предложений подчинено одному предмету речи. Между компонентами в данном случае наблюдается анафорическая связь, которая отражает последовательное развитие основной мысли: онлайн-киңәшмә уздырды (провел онлайн-совещание) - Киңдшмәдә даими вәкилләре катнашты (в совещании приняли участие постоянные представители) - Алар искәртте (они подчеркнули). В этом ССЦ устанавливаются перечислительные отношения между предложениями. 
В следующем нашем примере сочинительная связь частей ССЦ представлена сочинительным союзом hәм (и):

Бездә уку-укыту системасы дәүләтнең төп законына буйсынган. Теләсә кем аны теләсә ничек үзгәртә алмый. Һәм үзгәртмәскә тиеш (Татар-информ, 21.09.2021). / У нас образовательная система подчиняется основному закону государства. Любой желающий не вправе его менять. И не должен.

Между компонентами первого и второго предложений наблюдается анафорическая связь, которая представлена словосочетанием төп закон (основной закон) и личным местоимением аны (его).

В современных медиатекстах часто встречаются ССЦ с противительными отношениями между компонентами. Предложения, которые входят в состав таких ССЦ, создают семантико-грамматическое единство. В них главным является то, что такие сообщения строятся именно путем передачи присущих отдельным предложениям ССЦ противоречий.

Татарстан Гидрометеорология һәм дйләнә-тирә мохитне күзәтү үздге хәбәр иткәнча, бүген республикада жылы һава торышы саклана әле, ягъни +11 градус булачак.

Әмма иртәгә, 2 ноябрьдә, һава шарлары начарлана башлый. Төбәк буенча урыны белән жепшек кар һәм яңгыр көтелә. Аязучан болытлы һава торышы була, жүил башта төньяк-көнбатыштан, аннары көнчыгыштан уртача тизлектә исәчәк. Төнлә һава температурасы 0,+5 градус көтелә. Көндез +3,+8 градуска кадәр жылыта, дип хәбәр итә синоптиклар (Татар-информ, 01.11.2021). / Как сообщает центр по гидрометеорологии и мониторингу окружающей среды Республики Татарстан, сегодня в республике еще сохранится теплая погода, то есть будет +11 градусов.

Но завтра, 2 ноября, погодные условия начнут ухудшаться. По региону местами ожидается мокрый снег и дождь. Ожидается переменная облачность, ветер сначала северо-западный, затем восточный умеренный. Температура воздуха ночью составит $0,+5$ градусов. Днем потеплеет до +3, +8 градусов.

В нашем примере ССЦ передает единый смысл - на сегодня в республике установлена сравнительно теплая погода, но на завтра ситуация заметно изменится. ССЦ состоит из двух противительных частей, вторая из которых оформлена абзацем и противительным союзом әмма (но).

Противопоставление в таких ССЦ передается также различными средствами связи. Чаще всего употребляется противительный союз әмма (но):

«Драма әсәрләре йомшаграк, икенче һәм өченче урыннар белән чикләнербез дип торам. Прозада югары балл куярлык әсәр бар. Әмма гомуми баллар башка әгъзалар белән киңәшләшкәннән соң гына куела, без объектив булырга тырышабыз», - диде жюри, әдәбият галиме Әлфәт Закиржанов (Татар-информ, 16.11.2020). / «Драматические произведения слабые, думаю, что ограничимся вторыми и третьими местами. В прозе имеются произведения, заслуживающие высокие баллы. Но общие баллы будут выставлены лишь после того, как посовещаемся с остальными членами, мы стараемся быть объективными», - сказал член жюри, литературовед Альфат Закирзянов.

ССЦ также состоит из двух частей, которые противопоставляются друг другу. Они представляют семантикосинтаксическое единство, так как суть сообщения состоит именно в передаче присущих ему противоречий.

В следующем ССЦ противопоставленная часть, помимо союза әмма (но), выделяется еще и абзацем. Тем самым подчеркивается ее семантическая значимость:

Коронавирус инфекциясе үпкәнең стеналарында «тишекләр» барлыкка килұгә сәбәпче булырга мөмкин. Бу хакта ига.ти агентлыгы табиб-пульмонолог Сергей Пурясевка сылтама белән хәбәр итә.

Аның сүзләренчә, мондый тишекләр күбесенчә эчкечеләрдә, трофик тайпылышлар күзәтелгән пациентларда, шулай ук начар тукланучы кешеләрдә ачыклана.

«Әмма мондый очраклар да була: агрессив инфекция “очып” килеп, сау-сәламәт кешеләр багана кебек авып төшәргә дә мөмкин», - дип өстәде Пурясев (Татар-информ, 31.10.2021). / Коронавирусная инфекция может стать причиной образования «дыр» в легких. Об этом сообщает агентство ura.ru, ссылаясь на слова врачапульмонолога Сергея Пурясева.

По его словам, такие дыры чаще всего выявляются у алкоголиков, пациентов с трофическими нарушениями, а также у людей, плохо питающихся.

«Но бывают и такие случаи, когда агрессивная инфекция может повалить и здорового человека», - добавил Пурясев.

Также союз гәрчә (хотя) может выражать противительное отношение между предложениями ССЦ, хотя данное средство связи встречается не часто.

Балтач районында заманында элекке СССР күләмендә данланган (рекорд арты рекорд куйган комсомоляшьләр фермасы белән танылды) Салавыч Сәрдегәне дигән авыл бар. Биредә электән бик булган, тырыш халык яши. Шушы жирлектә үскән Ирек тә искәрмә түгел. Гәрчә тамырлары белән бу авылдан булмаса да (Ватаным Татарстан, 25.06.2019). / В Балтасинском районе расположена деревня Салаусь-Сардыган, которая в свое время была известна всему СССР (прославилась фермой комсомольской молодежи, ставившей рекорд за рекордом). Тут издавна живет очень умелый, старательный народ. Не является исключением и Ирек, выросший в этой местности, хотя он и не является коренным жителем.

Часто в ССЦ средством связи выступают противительные союзы ләкин (но), тик, бары тик (но, только), которые также противопоставляют два мнения:

Базар системасына керу безнең алда шактый проблемалар тудырачак. Ләкин кыенлыктан куркып, бу процесска керми калу мөмкин түгел (Татар-информ, 21.09.2021). / Переход к рыночной системе создаст нам много проблем. Но нельзя, испугавшись трудностей, оставаться в стороне от этого процесса. Т.е., да, рыночная система, несомненно, создаст для нас трудности, но мы не должны их бояться. Или же:

Үз эшемне яратам. Бары тик акчасы аз булу гына бераз кимсетә (Татар-информ, 09.10.2020). / Свою работу люблю. Только немного смущает маленькая зарплата. 
Противительные союзы в ССЦ выражают и сопоставительное отношение.

Например: Ил халкының яртысы (52 процент) доллар бәясе алга таба да артачак дип саный. 2008 елгы кризис чорында мондый фикердә торучылар саны 30 процент тирәсе генә булган. Икътисадтагы хәлләр бар кешене нефть кенә түгел, доллар һәм евро бәяләрен дә күзәтеп барырга өйрәтте. Ә сез нефть һәм чит ил акчасының бәясен күзәтеп барасызмы (Ватаным Татарстан, 25.12.2015)? / Половина населения (52 процента) считает, что курс доллара в ближайшее время будет расти. При кризисе 2008 года сторонники такого мнения составляли всего 30 процентов. Ситуация в экономике научила людей следить не только за ценой нефти, но и за курсом доллара и евро. А вы следите за курсом нефти и иностранной валюты?

В данном ССЦ сопоставляются население страны и конкретный читатель, которому адресован вопрос. То есть в подобных ССЦ наряду с противительным союзом ә (а), средством связи является и риторический вопрос. Тем самым концовка ССЦ подчеркивает сопоставление, а не противопоставление.

Что касается ССЦ с причинными отношениями частей, то в таких ССЦ синтаксическими показателями становятся союзы чөнки (потому что), дгәр (если), союзное слово шуңа күрә (поэтому), вводные слова димәк (значит), хәер (хотя), юкса (иначе), ник дигәндә (почему) и др.

Мәсәлән, ящьләребезнең бер өлеше бик тырышып укымый. Чөнки университетка килде ни, китте ни. Аның бернинди матди файда яки зарар күрәсе юк. Биш-алты ел гына стипендия алып укыган булып йөрү белән кандгатьләнмича, кайбер вакытта ул процессны жиде-сигез елга житкерүчеләр бар (Татар-информ, 21.09.2021). / Например, часть молодежи не старается хорошо учиться. Потому что разницы нет: пришел в университет или нет. Они не испытывают никакой финансовой выгоды, либо ущерба. Есть и те, кому кажется мало этих 5-6 лет учебы, и они затягивают данный процесс на 7-8 лет.

- Балага исем эзләү бәби табудан да катлаулырак, - ди әни булырга әзерләнүче Миләүшә Исхакова. - Тиздән улыбыз туачак. Ирем Ранил белән сабыебызга гадәти булмаган, әмма гаиләбезгә якын исем кушарга телибез. Улыбыз әтисенд, әнисенә, нәселенә охшап тусын иде. Шуңа күрә Миран дигән исем сайладык. Ул Миләүшә һәм Ранил исемндреннән кыскартып ясалган (Ватаным Татарстан, 07.06.2019). / - Найти имя ребенку сложнее, чем родить ребенка, - говорит готовящаяся стать мамой Миляуша Исхакова. - Скоро у нас родится сын. Мы с мужем Ранилем ребенку хотим дать необычное, но близкое к семье имя. Хотим, чтобы сын был похож на папу и маму. Поэтому выбрали имя Миран. Оно образовано сокращениями от имен Миляуша и Раниль.

Как показывают примеры, во второй части ССЦ указывается причина микротемы, обозначенной в первой части. Тем самым именно вторая часть становится стерженевым компонентом ССЦ, а первая часть становится «подготовительным» компонентом ССЦ.

Бездә уку-укыту системасы дәүләтнең төп законына буйсынган. Теләсә кем аны теләсә ничек үзгәртә алмый. Һәм үзгәртмәскә тиеш. Әгәр үзгәрә икән, ул вакытта закон нигезендә үзгәрергә тиеш. Канунга буйсынырга тиеш. Юкса, башбаштаклык барлыкка киләчәк (Татар-информ, 21.09.2021). / У нас образовательная система подчиняется основному закону государства. Любой желающий не вправе его менять. И не должен. Если будут правки, то они должны быть обоснованы законом. Иначе, получится самоуправство.

В современных медиатекстах встречаются также ССЦ с причинно-следственными отношениями между предложениями. Средством связи часто выступают вводные слова димәк (значит), дөрес (правда), дйтик (скажем), хәер (хотя, впрочем), кыскасы (словом), юкса (иначе), чыннан да (действитеьно), ник дигәндә (почему) и др.

Кечкенд генә бер районда ничек итеп мондый ярыш уздырырга алынганнар? Көрәш жәмәгатьчелегендә еш яңгырады бу сорау соңгы көнндрдә. «Ничек дзерләнгәнне ұзебез генә беләбез инде. Бер алынгач, туктарга ярамый бит. Инде ничә көн йоклаган юк», - ди әнә райондагы түрәләрнең берсе. Хәер, йоклый алмаганнарына үзләре «гаепле». Ник дигәндә, Татарстанда мондый зур ярыш уздырырга карар кылган федерация вәкилләренең нәкъ менә Теләчене сайлавы гажәп тә түгел (Ватаным Татарстан, 17.12.2014). / Как в одном небольшом районе решили провести такое соревнование? В последние дни в борцовском сообществе этот вопрос часто звучал. «Как готовились, знаем только сами. Раз решились, нельзя же останавливаться. Сколько дней уже не спим», - говорит один из чиновников района. Впрочем, сами во всем «виноваты». Неудивительно, что представители Федерации, решившие провести в Татарстане такое крупное соревнование, выбрали именно Тюлячинский район.

В современных медиатекстах встречаются ССЦ и с присоединительными отношениями частей. При возникновении присоединительных отношений между компонентами ССЦ, оно структурно делится на две части, где в первой части передается основная мысль, а во второй присоединительной части сообщается информация о данной главной мысли. Такая информация в основном выражает мнение автора. И она в комплексе с первой основной частью раскрывает целостное содержание темы, предмета речи.

Лионель, Алена-Цветочек, Асфәт, Айдә, Полина-Полина! Былтыр Татарстанда яңа туган сабыйларга әнә шундый гадәти булмаган исемнәр кушканнар. Тик юкка баш ватканнар бугай. Бөтенроссия халык фикерен өйрәнү үзәге ұткәргән сораштырудан күренгәнча, илдә яшәүчеләрнең яртысы балага колакка ятышсыз исем кушучы әтиәниләрне хупламый (Ватаным Татарстан, 07.06.2019). / Лионель, Алена-Цветочек, Асфат, Айда, Полина-Полина! В прошлом году в Татарстане новорожденных назвали такими необычными именами. Но, похоже, зря. По данным опроса Всероссийского центра изучения общественного мнения, половина жителей страны не одобряют родителей, называющих ребенка непонятным именем.

Присоединительная конструкция в данном примере используется для усиления прагматического эффекта, а также для выражения авторского мнения. 


\section{Заключение}

Итак, выявив виды синтаксических отношений между компонентами сложных синтаксических целых в современных медиатекстах, рассмотрев структурно-семантические типы сложных синтаксических целых в медиатекстах и исследовав компоненты сложных синтаксических целых на основе их структуры и семантики, можно сделать вывод о наличии многообразных структурно-семантических типов. В результате анализа были выявлены сочинительные, противительные, сопоставительные, причинные, следственные, условные и присоединительные отношения между компонентами ССЦ. Проведенный анализ ССЦ показал, что чаще всего средством связи между компонентами ССЦ наблюдается анафорическая связь. Для передачи различных смысловых отношений употребляются союзы һәм (и), ләкин (но), тик, бары тик (но, только), әмма (но), гәрчә (хотя), чөнки (потому что), дгәр (если), союзное слово шуңа күрә (поэтому), вводные слова димәк (значит), хәер (хотя), юкса (иначе), ник дигәндә (почему), вводные слова димәк (значит), дөрес (правда), әйтик (скажем), хәер (хотя, впрочем), кыскасы (словом), юкса (иначе), чыннан да (действитеьно), ник дигәндә (почему) и др.

Несмотря на то, что были выявлены различные синтаксические отношения между компонентами ССЦ, они являются целостными грамматическими и семантическими единицами.

Перспективы дальнейшего исследования проблемы мы видим в комплексном изучении ССЦ в татарском языкознании, структуры, функционального предназначения ССЦ.

\section{Источники | References}

1. Гарифуллин В. 3. Типы структурной организации журналистского текста. Казань: Тат. кн. изд-во, 1997.

2. Гарифуллин В. 3. Каләм көче (татар журналистикасында текст төзү осталары). II китап. Казан: Казан ун-ты, 2010.

3. Закиев М. 3. Татарская грамматика. Казань, 1995. III том. Синтаксис.

4. Зәкиев М. 3. Татар грамматикасы: өч томда. Казан: ТәһСИ, 2017. III т.

5. Зәкиев М. З. Хәзерге татар әдәби теле (синтаксис). Казан, 1974.

6. Ибраһимов С. М. Сандугач теле кирәк: синтаксик стилистика. Казан: Татар. кит. нәшр, 2008.

7. Низамов И. М. Татарча әдәби редакцияләү. Казан: Казан ун-ты, 2012.

8. Поспелов Н. С. Проблема сложного синтаксического целого в современном русском языке // Ученые записки Московского государственного университета. М., 1948. Вып. 137.

9. Шәкүрова М. М. Тел һәм сөйләм материалы буларак текст // Филология в полиэтнической и межконфессиональной среде: состояние и перспективы: международная научно-практическая конференция (11 июня 2015 г.). Казань: РИИ, 2015.

10. Шәкүрова М. М., Гыйниятуллина Л. М. Әдәби әсәргә лингвистик анализ ясау (татар әдәбияты һәм фольклоры мисалында). Казан, 2018.

\section{Информация об авторах | Author information}

RU Гиниятуллина Лилия Миннулловна ${ }^{1}$, к. филол. н., доц. Шакурова Муслима Магесумовна ${ }^{2}$, к. филол. н., доц.

${ }_{1,2}$ Институт языка, литературы и искусства имени Г. Ибрагимова

Академии наук Республики Татарстан, г. Казань

EN Giniyatullina Liliya Minnullovna ${ }^{1}, \mathrm{PhD}$

Shakurova Muslima Magesumovna ${ }^{2}, \mathrm{PhD}$

${ }^{1,2}$ Institute of Language, Literature and Art named after G. Ibragimov

of the Academy of Sciences of the Republic of Tatarstan, Kazan

1'gin_liluk@mail.ru, 2mshakurova@inbox.ru

\section{Информация о статье | About this article}

Дата поступления рукописи (received): 02.11.2021; опубликовано (published): 28.12.2021.

Ключевые слова (keywords): текст; сложное синтаксическое целое; медиатекст; структурные и грамматические средства связи; татарский язык; text; complex syntactic unity; media text; structural and grammatical connection means; Tatar language. 